\title{
Tanulmányok
}

\section{TUDÁS LÉTREHOZÁSA TÁRSADALMI HATÁSSAL KARÖLTVE: A RÉSZVÉTELI AKCIÓKUTATÁS (RAK) MEGKÖZELIITÉSE}

\section{KNOWLEDGE PRODUCTION HAND-IN-HAND WITH SOCIAL CHANGE: THE APPROACH OF PARTICIPATORY ACTION RESEARCH (PAR)}

\author{
Málovics György \\ $\mathrm{PhD}$, egyetemi docens \\ Szegedi Tudományegyetem Gazdaságtudományi Kar Kutatóközpont \\ malovics.gyorgy@eco.u-szeged.hu
}

\begin{abstract}
ÖSSZEFOGLALÁS
Napjainkban a társadalomtudományokat gyakran éri az a vád, hogy elszakadtak a gyakorlati élettől, nem bírnak érdemi gyakorlati relevanciával. Emellett, legalábbis hazánkban, semmi sem garantálja, hogy a társadalomkutatási eredmények érdemben beépülnek a közpolitikai (szakpolitikai) döntéshozatalba.

A fenti kihívásokra egy lehetséges válasz a részvételi akciókutatás (RAK) megközelítése, amely egyszerre kíván jó minőségű tudást létrehozni és közvetlenül hozzájárulni a társadalmi változásokhoz. Ennek érdekében kutatók működnek együtt jellemzően a társadalom peremére szorult (marginalizált) közösségekkel/emberekkel („laikusokkal”, érintettekkel), szabályozott (strukturált) keretek közt, cselekvésorientált módon.

Tanulmányunkban bemutatjuk a RAK megközelítését, annak főbb jellemzőin és elemein, valamint a megközelítéssel kapcsolatos dilemmákon keresztül. Megmutatjuk, hogy a konvencionális társadalomkutatási folyamatokhoz képest a RAK számos szempontból komoly kihívás elé állíthatja a kutatókat, ugyanakkor egyszerre kínál lehetőséget a jó minőségű tudás létrehozására, valamint arra, hogy e tudás egyből pozitív társadalmi változások eszközéül is szolgáljon.
\end{abstract}

\section{ABSTRACT}

A frequent critique towards social sciences that they have been separated from social practice and their results are not relevant for practical problem solving. Also, at least in Hungary, lacking science-policy interfaces scientific results hardly enter into social policies.

The approach of participatory action research (PAR) is one potential answer to the earlier limitations. PAR aims to generate good quality (scientific) knowledge hand-in-hand with contributing to social change. In order to fulfill these multiple goals, researchers work together with (usually marginalized) non-researcher social actors ('lay' stakeholders) in an action-oriented way. 
Present study introduces the approach of PAR through its core elements and related dilemmas. We show that PAR might pose significant challenges for social researchers on one hand, but provides an opportunity to produce good quality knowledge and contribute to meaningful social changes at the same time on the other hand.

Kulcsszavak: társadalomkutatás, részvételi akciókutatás, marginalizált csoportok, társadalmi hatás, képessé tétel

Keywords: social research, participatory action research, marginalized social groups, social impact, empowerment

\section{BEVEZETÉS}

Az akciókutatás (AK) „megpróbálja újra összekapcsolni a cselekvést a reflexióval, az elméletet a gyakorlattal, másokkal együttmüködésben, az embereket foglalkoztató problémákkal kapcsolatos gyakorlati megoldások keresésére" (Reason-Bradbury, 2001, 1.).

Az akciókutatási megközelítések családjába tartozó részvételi akciókutatás (RAK) ezen túlmenően komoly hangsúlyt helyez a kutatás „demokratizálására”, a kutató-kutatott viszony átalakítására, a folyamatban részt vevő felek érdemi és egyenlö részvételi lehetőségének biztosítására. Így a RAK célja többes (BradburyHuang, 2010). Fontos (1) a folyamat során eltervezett akciók megvalósítása, a problematikusként azonosított helyzet megváltoztatása; (2) a megismeréssel kapcsolatos célok teljesülése, azaz egy strukturált társadalomkutatási folyamat létrehozása, illetve (3) az emancipatorikus cél: a résztvevők képességeiben bekövetkezett változás, azaz képessé tétel (empowerment).

Jelen tanulmányban a RAK megközelítését mutatjuk be. Először röviden kitérünk a RAK ontológiai és episztemológiai alapjaira, majd a RAK alapvonásaira, folyamatára, mielőtt a 'részvétel', 'akció', 'kutatás' és 'képessé tétel' fogalmain keresztül bemutatjuk a RAK föbb jellemzőit és a folyamat során jelentkező dilemmákat.

\section{ONTOLÓGIAI, EPISZTEMOLÓGIAI SZEMPONTOK}

Számos olyan megközelítés (paradigma) létezik, amely a RAK ontológiai és episztemológiai alapjai kapcsán jelentőséggel bír (Reason-Bradbury, 2001; Bodorkós, 2010; Pataki-Vári, 2011; Greenwood, 2015). Az alábbiakban ezek közül emeljük ki a tanulmányunk szempontjából lényegeseket. 
Ontológiai szempontból a RAK szerint mindenki lényeges tudás birtokosa a társadalmi változási folyamat tervezése és kivitelezése kapcsán (Greenwood, 2015). Ezen túlmenően a legfontosabb ontológiai kiindulási alapok a RAK számára a pragmatista filozófia, valamint a kritikai elmélet (Bodorkós, 2010). A pragmatista filozófia szerint az elméletek és a gondolatok annyiban hasznosak, amennyiben a gyakorlatban müködnek (képesek változást előidézni). Ebből fakadóan a RAK a jó minőségű tudás termelését egyértelműen összeköti a változtatás képességével.

A kritikai elmélet nem fogadja el (megkérdőjelezi) a jelenlegi gazdasági és társadalmi berendezkedés fó céljait - gazdasági növekedés, profitmotívum, termelékenység -, csakúgy, mint a szakértő vagy bürokratikus tudás vagy éppen a fogyasztói életmód felsőbbrendüségét (Bodorkós, 2010). Ugyanígy nem fogadja el a társadalomban tapasztalható elnyomást, egyenlőtlenséget és igazságtalanságot. Ebből fakadóan a RAK egyik legfőbb célja a fennálló elnyomás, igazságtalanságok és hatalmi viszonyok megváltoztatása demokratikus módon. A RAK-ban emiatt (akadémiai) kutató szereplők leginkább valamely társadalom peremére szorult (marginalizált) csoporttal müködnek együtt - például menekültekkel/bevándorlókkal, HIV-fertőzöttekkel, autizmussal élők érdekében, tartós munkanélküliekkel, transznemúekkel, hajléktalan emberekkel, elnyomott nőkkel, szexmunkásokkal vagy éppen mélyszegénységben élő, sokszor elöítéletek által is sújtott, stigmatizált (afroamerikai, roma) közösségekkel -, ahogyan azt a terület talán legszínvonalasabb folyóiratában, az Action Researchben (URL1) megjelenő írások fókusza is mutatja. A közösen azonosított probléma válik kutatási problémává, a részt vevő marginalizált csoport problematikus helyzete pedig megváltoztatandó helyzetté.

Episztemológiai szempontból fontos hangsúlyozni, hogy a RAK nyiltan vállalt értékekre épít (Bodorkós, 2010; Greenwood, 2015). A társadalmi részvétel értékének megfelelően a RAK optimális esetben mindegyik érintett szereplőt bevonja az adott probléma vizsgálatának és a változtatásnak a folyamatába. A társadalmi igazságosság, egyenlöség értékének megfelelően a RAK felszabadító (emancipatorikus) jellegü: célja az érintettek megszabadítása az őket sújtó elnyomó feltételektől. A kritikai szubjektivitás, és gadameri episztemológiai alapállás (Bodorkós, 2010; Greenwood, 2015) eredményeképpen a RAK szerint tudásunk szükségszerüen magán hordozza nézőpontunk (horizontunk) hatását, aminek tudatában vagyunk, és ezt kifelé is kommunikáljuk. A RAK szerint a jó minőségű tudás előállításához így szükséges a nézőpont(ok)ra történő (csoportos) (ön)kritikai reflexió, és a transzparencia nézőpontunkkal és annak a megismerési folyamatot potenciálisan befolyásoló hatásaival kapcsolatban. 


\section{A RAK JELLEMZÖI, FOLYAMATA}

A RAK föbb jellemzői kapcsán eltérő szakirodalmak eltérő tipológiákat adnak meg (Bodorkós, 2010; Bradbury-Huang, 2010; Dick, 2015; Coghlan-Brydon-Miller, 2015). Ezek alapján a RAK:

- társadalomkutatási folyamat: szisztematikus, „tudományos igényü” megismerési folyamat;

- együttmüködő: a részt vevő kutatók és érintettek folyamatos, rendszeres együttmüködésén alapul a kutatási kérdések meghatározásától az eredmények publikálásáig;

- akcióközpontú: lényegi eleme az akció, a folyamat nem áll meg az elemzésénél és a publikálásnál, hanem az eredményekre építve a résztvevők az érintettek javát szolgáló akciókat igyekeznek megvalósítani.

A RAK tehát nem egyszeri kutató-kutatott interakción, hanem a résztvevők folyamatos együttműködésén alapul (1. táblázat), így nem kizárólag a kutató (kutatást finanszírozó intézmény) érdeklődése (probléma- és kérdésfelvetése) határozza meg a kutatás fókuszát, hanem ugyanígy számítanak ennek kapcsán a nem kutató/,,laikus” szereplök (partnerek) preferenciái.

Emellett a RAK nem áll meg a megfigyelés eredményeinek szakmai-megbízói irányba történő publikálásánál. A résztvevők közösen birtokolják a folyamat eredményeit, döntenek a publikációs formákról, lehetőségekről. Optimális esetben a kutató-laikus megkülönböztetés teljesen megszünik, a „laikus” résztvevők is „,teljes értékű kutatóvá” válnak, akár tudományos publikációk szerzőiként (lásd például Csécsei et al., 2017). Emellett a közös tudás alapján létrejövő akciók a folyamat elkülöníthetetlen részét képezik, és egyfelöl a tudás müködőképességének tesztelésére (Bodorkós, 2010), másfelől annak új aspektusokból történő megvizsgálására szolgálnak. A RAK-ban az akciók nagyon sokfélék lehetnek, a hazai gyakorlatban találunk példát (Pataki-Vári, 2011; Málovics et al., 2018; Csécsei et al., 2017; Csillag et al., 2017; Bodorkós-Pataki, 2009; Gosztonyi, 2017):

- oktatási programok és támogató hálózatok müködtetésére;

- a helyi politikai döntéshozatal befolyásolására tett együttmüködő kísérletekre környezeti és társadalmi ügyekben;

- az adott probléma érintettjeinek hálózatosodását szolgáló tevékenységekre;

- a részt vevő intézmények és intézményrendszer fejlesztésére;

- helyi szegénységenyhítő, fejlesztő programok megvalósítására;

- kistérségi stratégiaalkotási folyamatok demokratizálására, facilitálására;

- helyi élelmiszer-hálózatok létrehozására;

- tájfajták védelmét szolgáló programokra; valamint

- emberi erőforrás menedzsmenttel kapcsolatos etikai dilemmák vizsgálatára. 
1. táblázat. Részvételi akciókutatás és konvencionális kutatás - a folyamatok összehasonlítása

\begin{tabular}{|c|c|c|}
\hline & Részvételi kutatás & Hagyományos kutatás \\
\hline Miért folyik a kutatás? & Megértés és cselekvés & $\begin{array}{l}\text { Megértés, esetleges későbbi } \\
\text { cselekvéssel }\end{array}$ \\
\hline Kiért folyik a kutatás? & $\begin{array}{l}\text { A helyi érintettekért } \\
\text { (közösségért) (és az intézményi, } \\
\text { személyes és szakmai érdeklödés } \\
\text { kielégítéséért) }\end{array}$ & $\begin{array}{l}\text { Intézményi, személyes } \\
\text { és szakmai érdeklődés } \\
\text { kielégítéséért }\end{array}$ \\
\hline Kinek a tudása számít? & Helyi érintettek, kutatók & Kutatók \\
\hline $\begin{array}{l}\text { Mi befolyásolja a témák } \\
\text { kiválasztását? }\end{array}$ & $\begin{array}{l}\text { A helyi prioritások (és a } \\
\text { finanszírozó prioritásai, } \\
\text { intézményi forgatókönyvek, } \\
\text { szakmai érdekek) }\end{array}$ & $\begin{array}{l}\text { Finanszírozó prioritásai, } \\
\text { intézményi forgatókönyvek, } \\
\text { szakmai érdekek }\end{array}$ \\
\hline $\begin{array}{l}\text { Minek az érdekében } \\
\text { választják meg a } \\
\text { módszertant? }\end{array}$ & $\begin{array}{l}\text { Képessé tétel, közös tanulás, } \\
\text { társadalomtudományi } \\
\text { kutatásmódszertani szempontok }\end{array}$ & $\begin{array}{l}\text { Diszciplináris hagyományok, } \\
\text { „objektivitás” és ,igazság” }\end{array}$ \\
\hline \multicolumn{3}{|l|}{ Ki vesz részt a kutatásban? } \\
\hline Probléma azonosítása & Helyi emberek, kutatók & Kutatók \\
\hline Adatgyüjtés & Helyi emberek, kutatók & Kutatók, kutatási segéderők \\
\hline Értelmezés & $\begin{array}{l}\text { Helyi koncepciók és keretek, } \\
\text { és diszciplináris fogalmak } \\
\text { és keretrendszerek }\end{array}$ & $\begin{array}{l}\text { Diszciplináris fogalmak, } \\
\text { keretrendszerek }\end{array}$ \\
\hline Elemzés & Helyi emberek, kutatók & Kutatók \\
\hline $\begin{array}{l}\text { Az eredmények } \\
\text { prezentálása }\end{array}$ & $\begin{array}{l}\text { Helyben elérhető és hasznos } \\
\text { a kutatók által más kutatóknak } \\
\text { vagy a finanszírozónak }\end{array}$ & $\begin{array}{l}\text { A kutatók által más } \\
\text { kutatóknak vagy a } \\
\text { finanszírozónak }\end{array}$ \\
\hline $\begin{array}{l}\text { Az eredményeken } \\
\text { alapuló akció }\end{array}$ & A folyamat lényeges eleme & $\begin{array}{l}\text { Elkülönült, és lehet, hogy } \\
\text { be sem következik }\end{array}$ \\
\hline Ki cselekszik? & $\begin{array}{l}\text { A helyi emberek külső } \\
\text { segítséggel vagy anélkül }\end{array}$ & $\begin{array}{l}\text { Külső ügynökségek } \\
\text { (esetlegesen) }\end{array}$ \\
\hline $\begin{array}{l}\text { Ki birtokolja az } \\
\text { eredményeket? }\end{array}$ & Megosztva & Kutatók \\
\hline Min van a hangsúly? & Folyamat és kimenetek & Kimenetek \\
\hline
\end{tabular}

Málovics et al., 2016, 188. 
A RAK-akcióknak általában szerves részét képezi a kutatási eredmények helyi (politikai, intézményi) közösség és nyilvánosság irányába történő publikálása (hazai példákhoz lásd Csécsei et al., 2017; Csillag et al., 2017; Málovics et al., 2018). Az eredmények kommunikációja tehát nem pusztán a tudományos-kutatói szféra irányába történik, hanem azzal a helyi közösség (lakosok, sajtó, intézmények, politikai döntéshozók stb.) is szembesülnek.

A fentiekből is látszik, hogy a RAK nem egy standardizált folyamat. Ami a RAK-folyamatokban közös, hogy ezek középpontjában a folyamatok együttmúködő jellegéből fakadóan a csoportos munka, megvitatás áll, ún. akció-reflexió fázisok követik egymást (Bodorkós, 2010; Dick, 2015).

Ezen akció-reflexió fázisok során a kutató és érintett résztvevők közösen és szisztematikusan reflektálnak az egyes cselekvésekre - a kutatás megtervezésétől a kutatási eredményeken alapuló cselekvésig, értékeléséig. E fázisok biztosítják, hogy a kutatás teljes folyamata során megjelenjen mind a helyi, érintetti tudás (és szempontok), mind pedig a kutató résztvevők (akadémiai) tudása. Azaz ez egyfajta minőségbiztosítás (Bodorkós, 2010), hogy a szereplők döntéseiket nagyon tudatosan hozzák meg, és ezeket, valamint következményeiket tudatos módon kezeljék. A gyakorlatban egy sok szereplőt bevonó és több tevékenységre kiterjedő RAK-folyamatban az akció-reflexió fázisok gyakran több skálán történnek, és nem anynyira szabályosak, mint ahogyan azt az elméleti akció-reflexió spirálok sugallják.

\section{RÉSZVÉTEL, AKCIÓ, KUTATÁS}

\subsection{RAK és részvétel}

A részvétel azt a követelményt állítja a RAK elé, hogy a valamiröl/valakikről (research on) folyó kutatást váltsa fel az érintettekkel együttmüködö (research with) jellegü kutatás. Egy ideális RAK-folyamatot a résztvevők teljes egyenrangúsága, a folyamatok teljes átláthatósága és a közös, minden érintett által azonos mértékben befolyásolható döntések jellemeznek (Bradbury-Huang, 2010; Dick, 2015).

A fenti ideálhoz azonban nem egyszerü felnőnie egy valós RAK-folyamatnak, mert a középosztálybeli akadémiai és marginalizált nem akadémiai együttmüködők közti társadalmi távolság, hatalombeli különbség a RAK folyamatába is szükségszerüen begyürüzik, és számtalan dilemmát vett fel. Hazai kontextusban például azzal kapcsolatban, hogy hogyan lehet ,egyenlő” alapon együttmüködést kialakítani kulturális, társadalmi és anyagi tőkével bőven ellátott középosztálybeli szereplők és stigmatizált, marginalizált, szegregált körülmények közt élő csoportok és tagjaik közt (Málovics et al., 2018).

Ezzel együtt a RAK-ban a kutató résztvevők törekszenek e RAK-ideálnak megfelelően részt venni. Így a RAK egy együttmüködő, minimum erősen konzultatív folyamat, ahol a kutató résztvevők elfogadják, elismerik legitimnek az 
érintettek szempontjait, érdeklődését, problémaészlelését és tudását - a kutatási probléma és kérdés megfogalmazásától kezdve egészen a publikálási folyamatig. Azaz a RAK tudatosan és szisztematikusan törekszik a hierarchikus kutató-kutatott viszony oldására, miközben tisztában van ennek nehézségeivel.

Az akadémiai és nem akadémiai szereplők hosszabb távú, partneri jellegü és akcióorientált együttmüködése kifejezetten alkalmassá teszi a RAK-ot arra, hogy jó minőségü, strukturált megismerési folyamatok jöjjenek létre marginalizált társadalmi csoportokkal együtt, velük kapcsolatban. A ,kutató-kutatott” viszonyt felválthatja a partneri kapcsolat, amely lehetőséget teremt a konvencionális kutatás/kutató előtt tabunak számító témák megvitatására is. A szegregált körülmények közt, mélyszegénységben élő roma közösségekkel kapcsolatos kutatások kapcsán például nemzetközi viszonylatban is népszerüek a kutató és nem kutató érintettek hosszabb távú, aktivizmust és tudományos megismerést kombináló folyamatok (lásd Málovics et al., 2018).

\subsection{RAK, akció, kutatás}

A RAK elkötelezett a beavatkozás (akció) iránt, amelyre egyrészt a szereplök által problematikusnak itélt helyzet megváltoztatásának, másrészt a tudástermelésnek az eszközeként is tekint (Greenwood, 2015). A RAK szerint: „Nem érthetsz meg igazán egy rendszert (helyzetet), amíg nem próbáltad azt megváltoztatni.” (Dick, 2015, 440.) Az akciók által a szereplők a megszerzett tudást egy új szempontból vizsgálhatják és érthetik meg, hiszen sem az elmélet nélküli gyakorlat (praxis), sem a gyakorlati relevancia (hatás, változtató képesség) nélküli elmélet nem teljes. Emiatt a RAK számára a tudás müködőképessége például annak vonatkozásában, hogy az az érintetteket felruházza a saját életükön való változtatás képességével (azaz a képessé tétel, empowerment) egyenesen a létrehozott tudás érvényességi kritériuma.

Ehhez képest a RAK tudományos minőségével kapcsolatos legfőbb kritikák éppen a megközelítés akcióorientált mivoltához kapcsolódnak (Bodorkós, 2010; Bradbury-Huang, 2010). Az egyik ilyen szerint, mivel a RAK-ban adott helyzetekhez keresünk megoldást és magyarázatot, így e magyarázat kontextusfüggő - a RAK így feláldozza az általánosíthatóságot a hasznosíthatóság érdekében. Ez azonban nem pusztán a RAK sajátja - az alacsonyabb fokú megbízhatóság és magasabb fokú érvényesség általában is jellemző a kvalitatív társadalomkutatási módszerekre. Másfelöl a RAK esetében az általánosíthatóság egy másik síkon jelentkezik: az alkalmazott módszerek alkalmazhatók lehetnek más problémákra - emiatt kiemelkedően fontos, hogy a kutató a módszertanról részletes leírást adjon.

A másik vonatkozó kritika az érzelmi elköteleződéshez, és ebből fakadóan a kiegyensúlyozottság, ,kutatói objektivitás” sérüléséhez kapcsolódik. A részvételi akciókutatók elismerik, hogy a beavatkozás (akció komponens) ténylegesen komoly érzelmi elköteleződést eredményezhet, sőt, ez egyenesen kulcsfontosságú 
egy hosszabb távú RAK-folyamat esetében, mert az hosszú távú, sokszor önkéntes elköteleződést igényel a szereplők részéröl - ilyen értelemben az érzelmi elköteleződés nem pusztán hozadéka, de (elö)feltétele is a RAK-nak.

E kritika kapcsán a RAK válasza kettős. Egyfelől a RAK annak korábban bemutatott kritikai realista alapállásából következően nem hisz az „objektív”, értéksemleges társadalomkutatásban - ilyen értelemben a felfedett kutatói beavatkozás és elköteleződés nem problematikusabb, mint amikor az értéksemlegesség álarca mögé bújva hozunk meg szintén komoly értékítéleteket hordozó döntéseket egy kutatási folyamattal kapcsolatban (például a vizsgált probléma és módszertan kapcsán). Másfelől a részvételi akciókutatók (f)elismerik, hogy „,az akciókutatás alapvető kihívása a mély empátia és politikai elkötelezettség egyedülálló kombinálása a kritikai és reflexív kutatással, amelynek értelmében a kutatónak saját tapasztalataitól is egy lépés távolságot kell tartania" (Levin, 2012, 134.). Azaz a RAK sikeréhez kutatói oldalról a közösségi aktivizmus és módszertani szigor egyensúlyának megtalálása szükséges.

A RAK esetében azonban a módszertani szigor is másképpen definiálódik. A konvencionális társadalomkutatást komoly módszertani szigor jellemzi - vannak olyan tudományterületi (paradigmatikus stb.) szabályok, amelyekhez egy jó megismerési folyamatnak tartania kell magát. A bevett tudományterületi módszerek alkalmazása a RAK esetében azonban messze nem kizárólagos szempont a létrejövő tudás minőségének megítélésében. Egyrészt, ahogyan említettük, a RAK-ban a létrejövő tudás minőségének elsődleges tesztje a gyakorlati müködöképességé, így a konvencionális módszertani szigorhoz való merev ragaszkodás még a RAK tudástermelési sikere ellenében is hathat.

A kommunikációs normák, szokások például alapvetően befolyásolják azt, hogy a módszertani szigort a RAK-ban mennyiben lehet érvényesíteni. A konvencionális, standardizált módszertanok precíz alkalmazásához való merev ragaszkodás könnyen a RAK kudarcához vezethet. A hosszabb távú együttmüködés és bizalom, és így a RAK megismeréssel és társadalmi hatással kapcsolatos potenciáljának kiaknázása érdekében fontos, hogy a kutató igyekezzen a kutatásban részt vevő partnerek „természetes” közegében mozogni, „természetes” szituációkban részt venni. Azaz fontos, hogy a kutató ne legyen túlzottan rámenős az általa kívánatosnak tartott logika (például szigorúan szabályozott megfigyelési standardok) „eröltetésében”, ha az idegen a partnerek természetes közegétől. Ez ugyanis a RAK valóságközeli jellegének elvesztéséhez, alacsonyabb fokú megértéshez, a szereplők közti bizalom lerombolásához és a folyamat elhalásához vezethet.

A fentiekből következően a módszertani szigor és minőségbiztosítás kiemelkedően fontos kritériuma a RAK esetében az átláthatóság (transzparencia). Ha az akciókutatásban egyetlen szabály van a minőség biztosítására, akkor az az, hogy a folyamat során felmerülő választási pontokkal és az ezekkel kapcsolatos döntésekből fakadó korlátokkal kapcsolatban átláthatóak legyünk (Bradbury-Huang, 2010). 


\subsection{RAK és képessé tétel}

A társadalmi változás kritérium kapcsán a RAK-ban lényegi elem (alapvető cél) a képessé tétel (empowerment), azaz hogy emberek, szervezetek és közösségek képessé válnak ügyeik irányítására (Málovics et al., 2018).

Bár a képessé tétel fogalma elvont (elméleti) síkon könnyen érthető, igen nehéz azt „aprópénzre váltani” - azaz valós folyamatokat értékelni abból a szempontból, hogy azok elérték-e a képessé tétel célját. Így a RAK vonatkozó teljesítményét sem lehet egyszerüen, kvantitatív indikátorokkal mérni.

A képessé tétel szintjei például az egyénitől a közösségiig terjedhetnek. Azaz amikor egy teljes RAK-folyamat sikerességét szeretnénk megítélni e szempontból, akkor szükségszerü értékválasztással találjuk szembe magunkat a tekintetben, hogy milyen szinten jelentkező változásokat fogadunk el képessé tételként. Itt szükségszerüen felmerül a „Kinek az értékelése a mérvadó?” kérdése is. Vajon adott RAK-folyamatot minden résztvevő ugyanúgy értékel? Azaz: létrejön egy ilyen folyamatban a képessé tétel és átalakulás kapcsán a szereplők közös jelentésvalósága (Gelei, 2002)? Ugyanott húzzuk meg a határokat, amikor képessé tételröl beszélünk? Honnantól tekinthető valaki saját ügyei irányítójának? Egységesek vagyunk-e ennek értékelésében? Nyilvánvaló, hogy a RAK mély részvételi, demokratikus elkötelezettségéböl fakadóan ezen értékelések szükségszerüen az érintettek értékeléséből következnek. De az már nem garantált, hogy ezekben egyet is kell érteniük a résztvevőknek.

Ezen túlmenően az, hogy egy RAK folyamat vezetett-e képessé tételhez, eltérő időtávon, eltérő módon értékelhető. A képessé tétel egyfajta hosszabb távú, viszszafordíthatatlan változást jelent, ugyanakkor a valóságban az egyéni-családi-közösségi folyamatok nem feltétlenül ilyen egyszerüek. A képessé tétellel kapcsolatos megítélés a folyamat során változhat is - hiszen a RAK lényege éppen annak reflexív mivoltában (is), az akció-reflexió (értékelö) szakaszokban (is) rejlik. Ezek biztosítják, hogy a szereplök a létrejövő tudás alapján folyamatosan (újra)értékelik a folyamatot, amely a RAK lényegi eleme.

Ráadásul mivel a RAK legtöbbször marginalizált társadalmi csoportokkal együttműködésben folyik, a képessé tétel nem egy egyszerü, gyors folyamat. Emiatt a RAK gyakran igen hosszú távú procedúra (például a konvencionális kutatási projektek időtávjához viszonyítva), amiben a képessé tétel céljának elérése óriási kihívás a résztvevők számára.

\section{5. ÖSSZEGZŐ GONDOLATOK}

Tanulmányunkban a részvételi akciókutatás (RAK) társadalomkutatási megközelítését mutattuk be. A RAK fö különbségei a konvencionális társadalomkutatási folyamatokhoz képest annak nyíltan vállalt (demokratikus, részvételi, 
egyenlöségpárti) értékelköteleződéséből, valamint az ezen értékekkel szorosan összefüggő együttmüködö, részvételi jellegéből és akcióorientált mivoltából fakadnak.

E jellemzők okozzák a megközelítés erősségeit és kihívásait is. A RAK a hoszszú távú elköteleződés, a közös cselekvés és partneri viszony következtében a mély megismerés, a megélt tapasztalat és a társadalomtudományi tudás gyakorlatban történő tesztelésének és újraértékelésének lehetőségét hordozza magában a társadalomkutató számára. Mindezt úgy, hogy közben a kutató a kutatási folyamattal számára értelmes (pozitív) társadalmi változásokhoz is hozzájárulhat.

Ugyanakkor a RAK-ban a jó minőségü tudásteremtés érdekében az elköteleződésnek távolságtartással, a módszertani szigor iránti igénynek pedig nagyfokú módszertani rugalmassággal és az ezekkel kapcsolatos őszinte, kritikai szembenézéssel és transzparens kommunikációval kell kiegészülnie, amelyek komoly kihívást jelenthetnek a konvencionális társadalomkutatási szemléletben szocializálódott társadalomkutató számára. Csakúgy, mint a RAK együttmüködő jellegéből fakadó alacsonyabb „kutatói kontroll”, valamint a RAK nehezen megragadható képessé tételi (empowerment) céljának érdemi teljesítése.

\section{KÖSZÖNETNYILVÁNÍTÁS}

A kutatást az EFOP-3.6.1-16-2016-00008 azonosítójú, EU társfinanszírozású projekt támogatta.

\section{IRODALOM}

Bodorkós B. (2010): Társadalmi részvétel a fenntartható vidékfejlesztésben: a részvételi akciókutatás lehetőségei. Doktori értekezés. Gödöllő: Szent István Egyetem Környezettudományi Doktori Iskola, http://szie.hu//file/tti/archivum/Bodorkos_B_ertekezes.pdf

Bodorkós B. - Pataki Gy. (2009): Local Communities Empowered to Plan? Action Research, 7, 3, 313-334. DOI: 10.1177/1476750309336720, http:/econ.core.hu/file/download/konf_agri/ bodorkos-pataki.pdf

Bradbury-Huang, H. (2010): What Is Good Action Research? Why the Resurgent Interest? Action Research, 8, 1, 93-109. DOI: 10.1177/1476750310362435, https:/actionresearchplus.com/ wp-content/uploads/2015/01/Action-Research-2010-Bradbury.pdf

Coghlan, D. - Brydon-Miller, M. (2015): The SAGE Encyclopedia of Action Research. London: SAGE

Csécsei I. - Csengei A. - Dósa M. et al. (2017): „Mikor van a tetteknek ideje, ha nem ilyenkor?!” Részvételi akciókutatás a magyarországi lakhatási mozgalmakról. Kovász, 21, tavasz-tél, 65-81. http://epa.oszk.hu/00700/00721/00028/pdf/EPA00721_kovasz_2017_01-04_053-063.pdf

Csillag S. - Balázs É. - Kocsis M. et al. (2017): „Volt egyszer egy élet, de egy ember nem élvezhette”. Akciókutatás a magyar autizmusellátó rendszer fejlesztéséért. Kovász, tavasz-tél, 21, 33-51. http://epa.oszk.hu/00700/00721/00028/pdf/EPA00721_kovasz_2017_01-04_033-051.pdf 
Dick, B. (2015): Reflections on the SAGE Encyclopedia of Action Research and What It Says about Action Research and Its Methodologies. Action Research, 13, 4, 431-444. DOI: 10.1177/1476750315573593, https://www.researchgate.net/publication/283906004_Reflections on_the_SAGE_Encyclopedia_of_Action_Research_and_what_it_says_about_action_research_and_its_methodologies

Gelei A. (2002): A szervezeti tanulás interpretatív megközelitése: a szervezetfejlesztés esete. PhD-disszertáció, Budapest: BCE, http://phd.lib.uni-corvinus.hu/171/

Gosztonyi M. (2017): A pénz zsonglőrei: A szegénységben élők pénzgazdálkodásának rendszere. Szociológiai Szemle, 27, 3, 4-26. http://unipub.lib.uni-corvinus.hu/3508/

Greenwood, D. J. (2015): An Analysis of the Theory/Concept Entries in the SAGE Encyclopedia of Action Research: What We Can Learn about Action Research in General from the Encyclopedia. Action Research, 13, 2, 198-213. DOI: 10.1177/1476750315573592, https://bit.ly/2R1C3Z8

Levin, M. (2012): Academic Integrity in Action Research. Action Research, 10, 2, 133-149. DOI: $10.1177 / 1476750312445034$

Málovics Gy. - Juhász J. - Mihók B. et al. (2016): Részvételi akciókutatás (RAK) - egy alternatív tátsadalomkutatási megközelítés a müködőképes tudásért és társadalmi változásokért. In: Sütő E. - Szirmai É. - Újvári E. (szerk.): Sodrásban: képzések, kutatások (1975-2015). Tanulmányok. Szeged: SZTE JGYPK Felnőttképzési Intézet, http://www.fk.jgytf.u-szeged.hu/tanszek/kozmuv/wp/wp-content/uploads/2016/05/Sodr\%C3\%A1sban-M\%C3\%A11ovics-\%E2\%80\%93-Juh\%C3\%A1sz-0E2\%80\%93-Mih\%C3\%B3k-\%E2\%80\%93-Szentistv\%C3\%A1nyi-\%E2\%80\%93-Nagy-.pdf

Málovics Gy. - Méreiné Berki B. - Pataki Gy. et al. (2018): Confronting Espoused Theories with Theories-in-Use: Challenges of Participatory Action Research (PAR) with Marginalized Communities in Contributing to Social Change and Theory Building. Action Research, in press, http://journals.sagepub.com/doi/abs/10.1177/1476750318774389

Pataki Gy. - Vári A. (szerk.) (2011): Részvétel - akció - kutatás. Magyarországi tapasztalatok a részvételi, akció és kooperativ kutatásokból. Budapest: MTA Szociológiai Kutatóintézet

Reason, P. - Bradbury, H. (2001): Handbook of Action Research. Thousand Oaks: Sage

Smith, L. - Bratini, L. - Chambers, D-A. et al. (2010): Between Idealism and Reality: Meeting the Challenges of Participatory Action Research. Action Research, 8, 4, 407-425. DOI: 10.1177/1476750310366043, https://journals.sagepub.com/doi/pdf/10.1177/1476750310366043

URL1: https://journals.sagepub.com/home/arj. 